\title{
Lasers in Additive Manufacturing
}

\author{
Andrew J Pinkerton \\ Department of Engineering, Lancaster University, Bailrigg, Lancaster LA1 4YR, United Kingdom \\ aj.pinkerton@lancaster.ac.uk
}

$+44(0) 1524593547$

\begin{abstract}
Additive manufacturing is a topic of considerable ongoing interest, with forecasts predicting it to have major impact on industry in the future. This paper focusses on the current status and potential future development of the technology, with particular reference to the role of lasers within it. It begins by making clear the types and roles of lasers in the different categories of additive manufacturing. This is followed by concise reviews of the economic benefits and disadvantages of the technology, current state of the market and use of additive manufacturing in different industries. Details of these fields are referenced rather than expanded in detail. The paper continues, focusing on current indicators to the future of additive manufacturing. Barriers to its development, trends and opportunities in major industrial sectors, and wider opportunities for its development are covered. Evidence indicates that additive manufacturing may not become the dominant manufacturing technology in all industries, but represents an excellent opportunity for lasers to increase their influence in manufacturing as a whole.
\end{abstract}

Keywords: Additive, Rapid, Manufacturing, Lasers, Review

\section{Introduction}

In the year if light, no one can deny that lasers have a significant influence in fields as diverse as telecommunications, instrumentation, medicine, computing and entertainment. In manufacturing their applications include processes such as cutting, drilling, welding, bending, cladding, cleaning, marking and heat-treatment $[1,2]$. They are being used more and at a growing range of scales; increasing powers enabling larger scale work and higher beam qualities and shorter pulse widths enabling smaller scale work. Financially, the global market for lasers is forecast at $\$ 9.7-11.7$ billion in 2015, and expected to be $\$ 16.0$ billion in $2020[3,4]$.

For a versatile tool with such an impressive existing portfolio of applications it may seem difficult to identify one area which is likely to be outstanding in the growth of use of the industrial laser over the 
next decade. However, one application has been singled out an invention that could remake the world and constitute a new industrial revolution $[5,6]$. Alternatively, in more detail, a revolutionary technology likely to restructure supply chains, relocate production facilities and profoundly alter the geopolitical, economic, social, demographic, environmental, and security landscapes [7, 8]. That process is additive manufacturing (AM). Additive manufacturing began as a rapid prototyping technology, suitable for producing haptic models, and developed into what it is today: both a rapid tooling and a manufacturing technology, capable of producing fully functional parts in a wide range of materials, metallic, non-metallic and composite.

This paper then looks at additive manufacturing, the way it is likely to develop in the future and the role of lasers in it.

\section{Additive Manufacturing}

\subsection{Lasers in Additive Manufacturing}

Additive manufacturing processes are typically broken into seven categories according to ASTM Standard F2792 [9], as shown in Table 1. The operation of different AM systems and the relative advantages and disadvantages of the different technologies are described and reviewed in the literature (e.g. [10-13]). Although not holding a monopoly over AM, it is clear from the classification that lasers are required for three out of seven of the major categories and two out of three process categories with the capability to manufacture metallic components.

Table 1. Categories of Additive manufacturing, classified according to ASTM Standard F2792 [9] See end of paper

The development of AM systems into user-friendly, commercial units plus the need for safety, means the laser within them is not always obvious. Further, during AM of metals it is usually necessary to shield the build point from harmful oxidation, either by performing the whole operation in an inert chamber or using blown inert gas, requiring further removal of the user from the 'sharp end' of the manufacturing. To clarify exactly which types of lasers are used in AM, Table 2 lists some laserbased AM processes and systems and their lasers.

Table 2. Some major manufacturers of additive manufacturing equipment and their lasers 


\begin{tabular}{|c|c|c|}
\hline Category & Manufacturer: systems & Laser \\
\hline \multirow{3}{*}{$\begin{array}{l}\text { Directed energy } \\
\text { deposition }\end{array}$} & Optomec Inc.: LENS series & $400-1000 \mathrm{~W}$ fibre laser \\
\hline & Trumpf GmbH: TruLaser series & $\begin{array}{l}\text { TruDiode diode laser, up to } 6 \mathrm{~kW}(600 \\
\mathrm{nm})\end{array}$ \\
\hline & $\begin{array}{l}\text { Oerlikon Metco Group: } \\
\text { MetcoClad systems }\end{array}$ & $1-6 \mathrm{~kW}$ diode laser \\
\hline \multirow[t]{4}{*}{ Powder bed fusion } & $\begin{array}{l}\text { 3D Systems Inc.: ProX, sPro } \\
\text { and ProX SLM systems }\end{array}$ & $\begin{array}{l}30-200 \mathrm{~W} \mathrm{CO}_{2} \text { laser (for } \\
\text { thermoplastics) } \\
50-500 \mathrm{~W} \text { fibre laser (for metals) }\end{array}$ \\
\hline & $\begin{array}{l}\text { EOS GmbH: EOSINT, EOS M } \\
\text { and PRECIOUS M machines }\end{array}$ & $\begin{array}{l}30 \mathrm{~W}, 70 \mathrm{~W} \text { or } 2 \times 50 \mathrm{~W} \mathrm{CO}_{2} \text { lasers (for } \\
\text { thermoplastics) } \\
200 \mathrm{~W}-1 \mathrm{~kW} \text { fibre laser (for metals) }\end{array}$ \\
\hline & $\begin{array}{l}\text { SLM Solutions GmbH: SLM } \\
\text { systems }\end{array}$ & $\begin{array}{l}400 \mathrm{~W}-2 \times 1000 \mathrm{~W} \text { fibre laser (for } \\
\text { metals) }\end{array}$ \\
\hline & Renishaw: AM250 & $200 \mathrm{~W}$ or $400 \mathrm{~W}$ fibre laser \\
\hline \multirow[t]{2}{*}{$\begin{array}{l}\text { Vat } \\
\text { photopolymerisation }\end{array}$} & $\begin{array}{l}\text { 3D Systems Inc.: ProJet and } \\
\text { ProX SLA ranges }\end{array}$ & $\begin{array}{l}\text { Solid-state frequency tripled Nd: } \mathrm{YVO}_{4} \\
\text { laser }(354.7 \mathrm{~nm}) \text {, up to } 1.5 \mathrm{~W}\end{array}$ \\
\hline & $\begin{array}{l}\text { Envisiontec: Perfactory, Ultra, } \\
\text { Xede, Xtreme, 3D-Bioplotter } \\
\text { ranges }\end{array}$ & Not specified \\
\hline
\end{tabular}

Clearly, existing commercial AM systems currently utilise a wide range of lasers technologies. Powers range from around $1 \mathrm{~W}$ to $6 \mathrm{~kW}$, and wavelengths from the ultraviolet $(354.7 \mathrm{~nm})$ to the infrared (10.6 um). Requirements vary from process to process, but the need to match SLA lasers with the polymer absorption spectrum, the use of different lasers for different materials in the powder bed fusion bed category and the use of the shorter wavelength diode laser, despite poorer beam quality than the fibre laser for directed energy deposition (DMD), indicates absorption is a major factor for laser selection throughout. Use of systems with powers greater than $6 \mathrm{~kW}$ have also been demonstrated (e.g. [14]) and some industrial 'home-made' systems also exist, particularly in the DMD category.

\subsection{Additive Manufacturing Production}

One of the reasons use of AM is forecast to increase at such a rapid rate is that it expands the boundaries for a design engineer by offering a profoundly different approach to traditional subtractive methods. This can also allow a greater range of components to be made as a single part, reducing the material required and need for joining, by whatever means. However, these benefits can be negated by high costs. 
There are a number of factors that contribute to the unit production price of an AM part, some of which can be related to the volume of production and others to the degree of complexity and customisation of the part [15]. The former can be broken down to material cost, machine cost, build time, energy consumption, labour and indirect costs $[16,17]$. Despite the greater material efficiency typically achieved, material costs are high because the raw material can be more expensive than for conventional processes. This is particularly the case for metallic parts, produced via DMD, SLM or SLS. For example, Atzeni et al [18]. calculated the material costs needed for a sintered aluminium alloy part to be ten times higher than those for the conventionally produced part [18]. Machine costs are another large contributor to the unit cost, and typically the single largest cost for polymeric AM. Different studies have calculated their contribution to be between one-quarter and three-quarters of the costs of a part, with the three-quarter contribution coming when building using vat polymerisation [19-21]. Build time, energy consumption and labour cost make up a smaller components of overall cost and can all be minimised by using the machines efficiently, which for most processes means effectively using the whole of the available build space to maximise solid:cavity volume ratio. Currently the amount of energy consumed when producing the same part by AM can still be greater than that when using conventional manufacturing processes, often due to the longer process times. Studies have found that SLS and 3D printing are less energy efficient than injection moulding at all but low production volumes $[42,58]$. Sreenivasan and Bourell [22] identified major consumers of energy in SLS of nylon materials to be chamber heaters (37\%), stepper motors for piston control (26 $\%)$, roller drives (16\%), and the laser (16\%). Preparation and postprocessing costs are not included in many models, but Lindemann et al [21] estimated them to be the third largest contributor to overall costs after the machine and materials. The indirect costs such as factory overheads associated with the production can be assigned in different ways, accounting for factors such as mixed part production $[20,23]$ but for any commercially viable organisation are much lower than direct costs.

Taking all these costs together, what is most evident is that in a production environment the economies of scale with AM are insignificant compared with traditional methods, leading to Figure 1(a) (generalised from [8, 19-21, 24]). The current position of the 'breakeven' point due to the high AM machine, material, preparation and postprocessing costs mean large parts, high production volumes or rates, or high accuracy and surface finish quality typically render AM production more expensive than traditional manufacturing [25-27], although it must be remembered what is defined as 'high production volume' varies considerably from industry to industry.

The degree of complexity and customisation of the part has a significant contribution to the production cost of a traditionally manufactured part. Greater complexity can lead to increased machining time, operator time, additional tooling, need for custom tooling, more extensive certification, increased scrap, and the need to subcontract parts that cannot be made in house. In contrast, complexity of AM parts incurs minimal additional costs and any customisation can be done 
digitally and without the need for additional tools, again incurring minimal cost [15]. This leads to Figure 1(b), which shows that AM is better suited for parts with high complexity and/or customisation. Customised parts also help gain market advantage and command a premium price [5, $28,29]$.

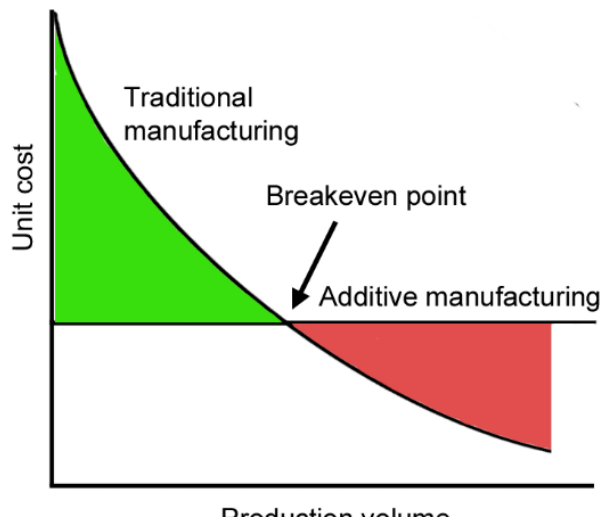

(a)

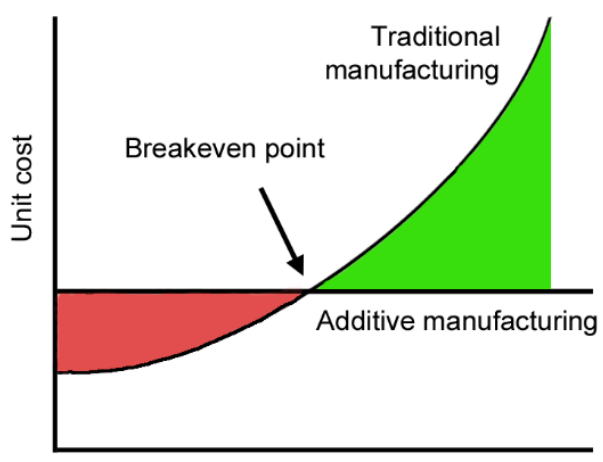

Complexity or Customisation

(b)

Figure 1. (a) Unit production cost for additive and traditional manufacturing; (a) against production volume; (b) against product complexity or customisation (adapted from [8, 15, 19-21, 24])

Beyond production, the effect of AM on the supply chain varies considerably from business to business, but there are many situations where it can impart savings, ether directly or by acting as an enabling technology for another process. At the beginning of 2011, the sum inventory in the manufacturing industry was $\$ 537$ billion (equal to $10 \%$ of that year's revenue) [17]. This ties up capital and building space (requiring maintenance, insurance, security etc.) and risks products deteriorating or becoming obsolete. Additive manufacturing has the potential to reduce this because, provided an inventory of suitable materials is available, it allows a wide range of parts to be produced on demand with no cost penalties for the rapid response. Another area of potential costs savings is 
transport costs. Additive manufacturing allows for the production of fewer, more integrated parts meaning there are simply fewer parts to transport.

An indirect benefit of AM, and potentially a very significant one, it that it is an enabling technology for remote direct digital manufacturing (DDM) [30]. Manufacturing closer to the point of sale using centrally transmitted data eliminates the need for part transport entirely and reduces the vulnerability to supply disruption for critical parts. The same on-site production method can then be used with the part (or one produced centrally) for rapid on-site production of replacement components. Although these factor can be overriding in same cases, for example use of a 3D printer in the International Space Station [31], analyses have indicated that in most circumstances AM machines are too specialised and expensive for this model to be cost effective at present $[32,33]$.

\subsection{The Additive Manufacturing Market}

Additive manufacturing is currently a $\$ 2.2$ billion trade with sales of products and services predicted to exceed $\$ 6$ billion by 2017 [34]. However, the uptake varies greatly across industries. It has had most penetration into the aerospace, automotive, electronics, and medical industries [27, 35], but other promising industries where it is used have been identified as armaments, furniture, jewellery, sports, speciality foods, surgical devices, textiles, toys, and tools and mould making [36].

In the first of these, the aerospace industry, metal AM techniques have been used for applications such as structural part, turbine blade and fuel injection nozzle manufacture and also for repair of worn blade tips and seals. Additive manufacturing can be more cost effective than traditional methods because the aerodynamic and weight-optimised shape of these parts means that with current methods buy-to-fly ratios can be low and the materials used are costly [37]. The exact savings versus traditional machining vary with market conditions: in one scenario they were estimated to be of the order of $15 \%$ and this is expected to increase with time [38, 39].

In the automotive industry it is currently cost effective to produce prototypes such as cylinder heads, brake rotors, and rear axles for testing via AM [40] and AM is also used in motor racing and for some luxury sport cars, for example intake manifolds, cylinder heads by Lamborghini [41]. However, 90.6 million motor vehicles were produced in 2014 globally [42] and the low production speed of AM is currently a major disadvantage for wider deployment in this industry. The industry does however make use of Rapid Tooling. Rapid Tooling is well developed within the tooling and moulds making industry generally and there are a range of different techniques including vacuum casting, metal spray tooling, and Keltool [43]. The short lead time of AM tooling can significantly reduce cost and time to market and improve the functionality and productivity of moulds [44]. 
Additive manufacturing technology is used in multiple ways in the medical and medical aid industries, which is ideally suited to the strength of AM in producing low volume, personalised parts [27]:

- In dentistry to produce digital prostheses such as bridges and crowns, invisible dental braces and alignment devices [45-47].

- In surgery to produce minimally invasive surgical tools, microtissue debriders, monolithically fabricated articulated biopsy forceps etc. [48].

- To manufacture artificial bone like material for joint replacement surgery, bone grafting orthopaedic implants and drug delivery devices [49, 50]. Integration of the scanning, designing and manufacturing stages allows complex and personalised biomedical parts to be obtained and such an approach and can significantly shorten the design and delivery cycle [51].

- As a rapid prototyping technology to produce biomodels for diagnosis, surgical training and pre-surgery planning. This is currently the single largest application in acute healthcare [52].

- $\quad$ To produce medical prostheses for example trans-tibial prosthesis [27] and body conformal aids, for example hearing aids [10]. The Additive Manufacturing of hearing aids is very well established, with almost global saturation.

Additive tissue manufacture has been used to produce simple biological tissues and organs but is at an early technology readiness level because both the manufacture (including multiple cells and materials) and design (to incorporate vascularization) of such structures is complicated. Structures are currently hydrogel based which lack the strength for larger parts and matching degradation to tissue development is difficult [53].

The electronics industry is another growth area for AM. From an electronic circuit production point of view, AM mean there is no need for mask preparation like conventional lithographic-based processes. This means microsystems can be prototyped faster, reducing development time and allowing more design iterations and optimization. With process optimization, electronics printing may also be more energy efficient than traditional lithography, although there is currently a lack of process data in this respect [54]. In addition to circuits, micro-electronic components can be produced; 3D manufacture via $\mathrm{AM}$ offers the functional advantage over 2 or $2.5 \mathrm{D}$ methods of allowing microstructures to be fabricated thin where flexibility is required and thick where rigidity is required [55]. The resolution of micro-stereolithography can be as small as $2 \mu \mathrm{m}$, and that of microlaser sintering and 3D printing as small as $20-30 \mu \mathrm{m}[10,56]$. There are now other areas for these 3D micro-AM processes beyond microelectronic products, including micro-opto-electro-mechanical systems (MOEMS), micro-optical electronics systems (MOES) and microelectromechanical systems (MEMS) [57] so expansion of this area is likely. 
Consumer industries include the sports, furniture, jewellery and toys industries, and if taken together represent another significant portion of the AM market. Additive manufacturing use is growing in all these fields. For example, laser sintering of snowboard components [58], integrated furniture manufacture [59], and even AM of teddy bears [60]! Its use for external devices conforming to the body is increasing because the effectiveness of devices such as breathing masks, fall-arrest harnesses, and sports protection bodywear is highly dependent on correct fit.

Several AM patents relating to Material Jetting, SLA, SLS and FDM, expired in 2014 and 2015 (e.g. [61-63]), leading to speculation that entry level versions of these machines will bring them firmly within the consumer domain. Currently this is not the case, but the number of open-source and other initiatives (e.g. Metalbot, OpenSLS, RepRap, MakerBot, UP3D) seem to be bringing it closer to a reality.

\subsection{Barriers to Additive Manufacturing}

The sectors described in the previous section are the success stories to date and are the industries usually discussed in reference to AM. But additive manufacturing as it is known today has existed for approximately 30 years [64] and it represents a limited number of industries. Current AM sales are still small compared with the machine tools industry, which had a global production value of around $\$ 60$ billion in 2014, and represent only about $0.01 \%$ of the $\$ 20.5$ trillion (nominal) in global manufacturing value added [65].

There are countless equity research organisations forecasting future markets and no consensus as to the exact scale of AM grown, but the current $\$ 2.2$ billion market value is generally predicted a compound annual growth rate (CAGR) between $20 \%$ and $45 \%$ [66, 67] [34]. This means AM will exceed the current machine tool market by either 2023 (45\% growth) or 2030 (20\% growth), but foreseeing the future is difficult and it is worth looking at the barriers to growth of AM. Gausemeier et al [36] compiled a table of success factors for AM in different industries, and this forms the basis for Table 3, which also divides the success factors into three categories: equipment, material and regulation. Some weaknesses are specific to individual processes, but many are common to all types. Surface quality, layer thickness, the ability to combine different manufacturing technologies, and the need to increase process repeatability and part reproducibility are all considered important 'process \& equipment' factors. Surface quality limitations can be seen as inherent to the layered manufacturing process (partially overlapping convex tracks on an upper surface plus the so called 'step effect') although methods to reduce this such as 'intelligent' slicing, process planning and a curved layer LOM process have been proposed [68-70]. It is always possible to post-process a part and to directly manufacture to near net shape with SLM and SLA by reducing layer thickness, but both these at the expense of build speed [71]. Layer thickness is seen as important; currently they are of the order 20100 um for SLS and SLM and 130-380 um for commercial DMD equipment [72]. In the future, more 
powerful lasers may contribute to this need, but increasing energy input leads to greater risk of surface vaporization and poorer surface quality, so greater power is equally likely to facilitate increase mass deposition rates via faster laying of tracks as via laying of thicker tracks.

Table 3. Relevant factors for additive manufacturing in different industries (adapted from [36])

\begin{tabular}{|c|c|c|c|c|c|c|c|c|c|}
\hline \multirow[b]{2}{*}{ 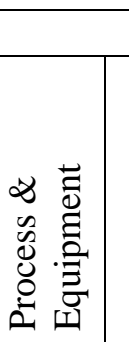 } & \multirow[b]{2}{*}{$\begin{array}{l}\frac{n}{\frac{\pi}{\bar{E}}} \\
\frac{\bar{N}}{\Sigma}\end{array}$} & \multirow[b]{2}{*}{ 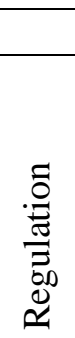 } & \multirow[b]{2}{*}{ Success Factor } & & \multicolumn{5}{|c|}{ Industries } \\
\hline & & & & 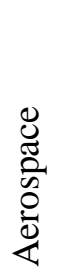 & 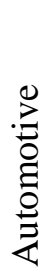 & $\begin{array}{l}\frac{n}{0} \\
\bar{z} \\
\sum_{\infty} \\
\infty \\
0 \\
0 \\
0\end{array}$ & 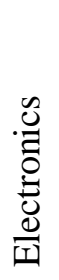 & $\frac{\tilde{J}}{\stackrel{0}{0}}$ & $\begin{array}{l}\text { ष् } \\
\bar{\Xi} \\
\overline{0} \\
\overline{0}\end{array}$ \\
\hline & & & Surface Quality & $\bullet$ & $\bullet$ & $\bullet$ & $\bullet$ & $\bullet$ & - \\
\hline & & & Layer Thickness & $\bullet$ & $\bullet$ & $\bullet$ & $\bullet$ & $\bullet$ & $\bullet$ \\
\hline & & & Process Speed & $\bullet$ & $\bullet$ & - & $\bullet$ & - & $\bullet$ \\
\hline & & & Combination of Manufacturing Technologies & $\bullet$ & - & - & $\bullet$ & - & $\bullet$ \\
\hline & & & Build Size & $\bullet$ & $\bullet$ & $\bullet$ & - & - & $\bullet$ \\
\hline & & & Easy-to-Use CAD Software & - & - & - & - & $\bullet$ & $\bullet$ \\
\hline & & & Application Conform CAD Software & - & - & - & - & $\bullet$ & $\bullet$ \\
\hline & & & Easy to Transport Manufacturing Machines & - & - & - & - & - & $\bullet$ \\
\hline & & & Low Budget 3D-Scanner & - & - & - & - & - & $\bullet$ \\
\hline & & & $\begin{array}{l}\text { Process Repeatability and Part } \\
\text { Reproducibility }\end{array}$ & $\bullet$ & $\bullet$ & $\bullet$ & $\bullet$ & $\bullet$ & - \\
\hline & & & Multi-Material & $\bullet$ & $\bullet$ & - & $\bullet$ & $\bullet$ & $\bullet$ \\
\hline & & & Multi-Colour & - & - & - & - & - & $\bullet$ \\
\hline & & & Process Costs & - & $\bullet$ & $\bullet$ & $\bullet$ & $\bullet$ & $\bullet$ \\
\hline & & & New Materials & $\bullet$ & $\bullet$ & $\bullet$ & $\bullet$ & $\bullet$ & $\bullet$ \\
\hline & & & Strength of Materials & $\bullet$ & $\bullet$ & $\bullet$ & - & $\bullet$ & - \\
\hline & & & High Temperature Resistant Plastics & $\bullet$ & $\bullet$ & $\bullet$ & - & - & - \\
\hline & & & Biocompatible Materials & - & - & - & - & $\bullet$ & $\bullet$ \\
\hline & & & Control of Part Lifetime & $\bullet$ & $\bullet$ & $\bullet$ & - & $\bullet$ & - \\
\hline & & & Standardization & $\bullet$ & $\bullet$ & $\bullet$ & $\bullet$ & $\bullet$ & - \\
\hline & & & Risk Management & $\bullet$ & $\bullet$ & $\bullet$ & $\bullet$ & $\bullet$ & - \\
\hline & & & Quality Assurance Systems & $\bullet$ & $\bullet$ & $\bullet$ & $\bullet$ & $\bullet$ & $\bullet$ \\
\hline & & & Certifications & $\bullet$ & $\bullet$ & $\bullet$ & $\bullet$ & $\bullet$ & - \\
\hline & & & Design Rules & $\bullet$ & $\bullet$ & $\bullet$ & $\bullet$ & $\bullet$ & $\bullet$ \\
\hline
\end{tabular}

${ }^{\mathrm{A}}$ The furniture, jewellery, food, sports and textiles industries are taken as representative of consumer industries

Combining different technologies will be easier to implement in some cases than others. Optomec, Aurora and Stratsasys have previously demonstrated combined operation of 3D printing and Aerosol Jet to make a "smart wing" for a small drone, demonstrating the compatibility of these technologies 
[73]. This field is not well developed, but it is a need that could maybe be alleviated by combining different materials within the same process, and this is already possible in some industries. For example, manufacture of multicolour structures via FDM and manufacture of graded metallic structures or metal-matrix composites (MMCs) via DMD $[74,75]$ has been demonstrated.

The need for new materials is a factor in every sector. The current range of AM materials for all processes (atomised metal powders, proprietary polymeric powders, liquid photopolymers etc.) is restricted and much more expensive than traditional material feedstock. Nevertheless, increasing use of additive manufacturing may mean the cost of the raw materials reduces through economies of scale, reuse or standardisation of certain materials [76].

The need for quality assurance systems and design rules are also identified as widely important. The current lack of technical standards in AM slowing down it use for critical parts which may require long certification periods $[10,77]$. The use of AM and DDM together also raise many questions. The need for a suitable regulatory framework in order to prevent the circulation of harmful technologies in digitalised form is very clear now that a US company, Solid Concepts, is legally selling guns and gun parts produced via laser sintering [38, 78][79]. Additive manufacturing and DDM also have the potential to blur the lines between manufacturer, wholesaler and retailer, in which case matters like legal responsibility in the case of product failure need to be resolved [17]. Existing patent law has also been identified as barrier to the future success of additive manufacturing [80].

\section{The role of lasers in the future of additive manufacturing}

The major users of additive manufacturing are not expected to change significantly in the future midterm and have been identified as consumer products, direct medical components, transportation (automobile and aerospace), and tool and mould manufacturing [38]. Unless a wider range of industries can be incentivised to use AM in the future, the prediction that AM will change the way companies interact and global supply chains operate on a global scale [92] will not be accurate. Wholesale change from traditional to additive manufacturing requires a company's organisation and indeed whole culture to adapt in order to make it successful $[93,94]$ and analysis by Gilbert [95] points to AM having difficulty penetrating high threat markets, where competition is high. Both resource rigidity (failure to change resource investment patterns) and routine rigidity (failure to change organizational processes that use those resources) are potential barriers [95].

Considering these major users of the technology, the trends in them and potential AM technologies are summarised in Table 4. It is very clear that AM is capable of tackling major goals and trends in the industries and further that many, indeed most, of these processes are laser-based.

To grow further, and become the dominant technology that many predict it to be, AM will also need to break into new industries and the above analysis does not seem to provide many incentives for that, 
although some of the factor in Table 4 may also apply to other industries (for example 'Accelerated product development' is becoming increasingly important in all markets and 'ageing population' is likely to affect demand for many products). However, there are at least two other factors or opportunities that could incentivise wider take up of the technology:

Table 4. Trends in major additive manufacturing (AM) markets and the involvement of lasers

\begin{tabular}{|c|c|c|c|}
\hline Market & Trends / Goals [36, 46, 81-84] & Beneficial AM Processes & Lasers \\
\hline \multirow[t]{5}{*}{ Aerospace } & Demand for lightweight structures & DMD, SLM, SLS & $\bullet$ \\
\hline & Organic features & DMD, SLM, SLS & $\bullet$ \\
\hline & Interior customisation [85] & FDM, 3DP & - \\
\hline & Fuel reduction & DMD, SLM, SLS & $\bullet$ \\
\hline & Rapid tooling, fixturing & DMD, SLS & $\bullet$ \\
\hline \multirow[t]{4}{*}{ Automotive } & Demand for lightweight structures & DMD, SLM, SLS & $\bullet$ \\
\hline & Power train electrification [86] & - & - \\
\hline & Sustainable mobility [87] & - & - \\
\hline & Customisation & FDM, 3DP & - \\
\hline \multirow{4}{*}{$\begin{array}{l}\text { Medical } \\
\text { (dental, } \\
\text { implants) }\end{array}$} & Increasing demand (ageing population) & - & - \\
\hline & Minimally invasive surgery & SMS, SLM $[88,89]$ & $\bullet$ \\
\hline & Replication of anatomic structures & $\begin{array}{l}\text { SLS, SLA, FDM, 3DP, FDM } \\
\text { [49] }\end{array}$ & $\bullet$ \\
\hline & Biomaterial manufacture & SLS, SLA, FDM/PBE [90] & - \\
\hline \multirow[t]{4}{*}{ Electronic } & Accelerated product development & $\begin{array}{l}\text { Micro-SLS, SLA, AJ, 3DP } \\
\text { [55] }\end{array}$ & $\bullet$ \\
\hline & Embedded electronics & 3DP, AJ [91] & - \\
\hline & Miniaturization & Micro-SLS, SLA, AJ [55] & $\bullet$ \\
\hline & Smart microsystems & Micro-SLS, SLA, AJ [55] & $\bullet$ \\
\hline
\end{tabular}

\section{The Need to Reduce Environmental Impact}

There is increasing emphasis on the environmental impact of manufacturing and the future is likely to see increased pressures on energy and material consumption and greenhouse gas emissions. This has the potential to become a driver for AM in the future because studies have shown that in most cases where it is economic to apply AM, it is more efficient in terms of virginal material consumption and water usage, produces less pollution and requires less landfill [26]. 
Taking Aviation as an example: it is a major contributor to greenhouse gas emissions. In 2014 greenhouse gas emissions from aviation were $688 \mathrm{~m}$ tonnes or $2 \%$ of all human sources, and increasing globalisations means aircraft fuel use is projected to triple by 2050 [96, 97]. Thousands of tonnes of Aluminium Titanium and Nickel alloys and greenhouse gas emission reductions of between 92.1 and 215 million metric tons during production could potentially be saved by use of AM [35]. However, potentially even greater benefit may come from AM's ability to produce components with lighter weight, longer life or better recyclability. In independent studies, authors have identified aerospace fuel saving of $9-33 \%$ by use of AM, with consequential environmental impact [38], and reduction of $\mathrm{CO} 2$ emissions over the whole lifecycle of a part by nearly $40 \%$ via weight saving using DMLS [98]. If similar impact could be achieved in other industries that would be a major incentive for greater uptake of the technology.

To fully benefit from these savings, however, some advances in the AM processes are required. The amount of energy consumed when producing the same part by AM can be greater than when using conventional manufacturing processes, often due to the longer process times. Studies have found that SLS and 3D printing are less energy efficient than injection moulding at all but low production volumes where the energy to produce the mould dominates [30, 99]. Further, there are still potential occupation hazard, such as eye and skin irritation from metal and polymeric powders, and the difficulty in disposing of waste polymers such as epoxy resins, polycarbonates, nylons (polyamides) acrylates and styrenes, which have poor biodegradability has not been tackled [100].

Burkhart and Aurich [101] proposed a tentative framework for assessing environmental effect with respect to the automotive industry, Luo et al [102] a 'life stage' model for assessing the environmental effect of AM processes, and Le Bourhis et al [103] a predictive model of the environmental impact to aid designers. There is work to be done, but models of this type, plus attention to the current known environmental weaknesses of AM, may be able to promote it financially and morally - as a 'green' choice for the future.

\section{Opportunities for Integration}

Considering the range of manufacturing production and the multiple factors that affect a part's suitability for AM, it is unlikely to make traditional manufacturing processes obsolete or produce global architectural change in marketing [104][19]. This points to a future with manufacturing centralised to at least some degree, and including forming, subtractive and additive techniques together. As such, the success factor "Combination of Manufacturing Technologies" that has been identified for all industry sectors (Table 3) seems to be particularly significant, with the manufacturing technologies described extending beyond purely Additive. Integration of additive and subtractive technologies does currently exists in isolated areas. For example Microfabrica's EFAB process is a hybrid (additive/subtractive) process based on multilayer electrodeposition and 
planarization of at least two metals [105] and Karunakaran et al [106] proposed a weld deposition system capable of being retrofitted to a CNC machining centre. However, it is not something that is well developed at present.

Duflou et al [107] described the use of multi-machine resource and energy flow ecosystems within a factory, recycling energetic or physical flows within the process chain, and between process chains. If traditional and AM systems could operate together in this way it would also have a favourable environmental impact. A decision-making framework or model to assist in selecting the manufacturing method and machine to apply to a component based on size, material, geometric features and production factors would be highly beneficial for such integrated systems [8, 108-110].

The benefit of AM operating with traditional manufacturing as well as an independent industry become clear from the current scale of the two industries. If AM could make even a $1 \%$ increase in current global manufacturing profitability that would surpass the predicted output from the global AM industry alone more than 1000 times over (based on [34, 65]). This integration could also offer an excellent opportunity for lasers, which are known for their ability to remove materials. Coupling this with a laser-based AM process greatly increases the range of parts that can be produced and brings the prospect of the laser shopfloor closer.

\section{Summary and Conclusions}

Additive manufacturing is notable for its immense potential and growth rate rather than its current scale throughout manufacturing. Its impact to date has been in selected industries, particularly the aerospace, automotive, electronics, and medical industries. Although in certain markets, for example custom manufacture of hearing aids, it has proved commercially superior to traditional methods, it is currently cost effective in only a limited range due to barriers such as high equipment and material costs and lack of design standards.

Looking forward, trends in the markets of the major industrial users of the technology indicate additive manufacturing will become even more prevalent because it is well placed to tackle their goals. Reduction of equipment and material prices, and other factors such as the need reduce environmental impact, may provide an incentive for new industries to increase use of the technology. However, there is no compelling evidence that additive manufacturing will become a dominant technology, superseding subtractive (machining) and forming technologies. The future is thus more likely to see these technologies operating together.

Three out of the seven categories of Additive manufacturing are laser-based: directed energy deposition, powder bed fusion and vat polymerisation. Lasers of around $1 \mathrm{~W}$ to $6 \mathrm{~kW}$, and wavelengths from the ultraviolet $(354.7 \mathrm{~nm})$ to the infrared (10.6 um) are employed in current commercial systems. More powerful lasers, with better wall plug efficiency and better overall process 
control could perhaps contribute to some of the existing additive manufacturing process weaknesses: process repeatability and part reproducibility, layer thickness / deposition rate and high energy use. Looking forward, the need to combine different manufacturing technologies additive-additive and additive-subtractive and also the need to improve surface quality have been identified. These could offer excellent opportunities for lasers, which, in different forms, are capable of additive manufacturing, machining (cutting, drilling) and surface engineering, so could potentially fulfil all needs. As a crucial component of additive manufacturing systems, as well as an important industrial tool outside it, lasers have just as much potential to change manufacturing as additive manufacturing itself.

\section{References}

1. Steen WM, Mazumder J: Laser Material Processing, 4th edn. Pub. Springer-Verlag, London: 2010.

2. Ion J: Laser Processing of Engineering Materials. Pub. Elsevier Butterworth-Heinemann, Oxford: 2005 .

3. Research B: Global Markets for Laser Systems, Components and Materials. In.: BCC Research; 2015.

4. Overton G, Belforte DA, Nogee A, Holton C: Laser Marketplace 2015: Lasers surround us in the Year of Light. In: Laser focus World. PennWell Corporation; 2015.

5. Berman B: 3-D printing: The new industrial revolution. Business Horizons 2012, 55(2):155-162.

6. Weller C, Kleer R, Piller FT: Economic implications of 3D printing: Market structure models in light of additive manufacturing revisited. International Journal of Production Economics 2015, 164:43-56.

7. Campbell T, Williams C, Ivanova O, G B: Could 3D printing change the world? Technologies, potential, and implications of additive manufacturing. In: Strategic foresight report. Washington, DC, USA: Atlantic Council; 2011.

8. Achillas C, Aidonis D, Iakovou E, Thymianidis M, Tzetzis D: A methodological framework for the inclusion of modern additive manufacturing into the production portfolio of a focused factory. Journal of Manufacturing Systems 2014:in press.

9. International A: ASTM F2792-12a, Standard Terminology for Additive Manufacturing Technologies. In. West Conshohocken, PA; 2012.

10. Gibson I, Roson DW, Stucker B: Additive Manufacturing Technologies: Rapid Prototyping to Direct Digital Manufacturing. New York: Springer US; 2010.

11. Groover MP: Fundamentals of Modern Manufacturing: Materials, Processes, and Systems. New York: Wiley; 2012.

12. Guo N, Leu M: Additive manufacturing: technology, applications and research needs. Frontiers of Mechanical Engineering 2013, 8(3):215-243.

13. Wong KV, Hernandez A: A Review of Additive Manufacturing. ISRN Mechanical Engineering 2012. 
14. Miranda RM, Lopes G, Quintinob L, Rodrigues JP, Williams S: Rapid prototyping with high power fiber lasers. Materials \& Design 2008, 29(10):2072-2075.

15. Conner BP, Manogharan GP, Martof AN, Rodomsky LM, Rodomsky CM, Jordan DC, Limperos JW: Making sense of 3-D printing: Creating a map of additive manufacturing products and services. Additive Manufacturing 2014, 1-4:64-76.

16. Morrow WR, Qi H, Kim I, Mazumder J, Skerlos SJ: Environmental aspects of laser-based and conventional tool and die manufacturing. Journal of Cleaner Production 2007, 15(10):932-943.

17. Thomas DS, Gilbert SW: Costs and Cost Effectiveness of Additive Manufacturing. In.: National Institute of Science and Technology; 2014.

18. Atzeni E, Iuliano L, Salmi A: On the Competitiveness of Additive Manufacturing for the Production of Metal Parts. In: 9th International Conference on Advanced Manufacturing Systems and Technology. Mali Losinj, Croatia; 2011.

19. Hopkinson N, Dicknes P: Analysis of rapid manufacturing - using layer manufacturing processes for production. Proceedings of the Institution of Mechanical Engineers, Part C: Journal of Mechanical Engineering Science 2003, 217(1):31-39.

20. Ruffo M, Tuck C, Hague R: Cost estimation for rapid manufacturing - laser sintering production for low to medium volumes. Proceedings of the Institution of Mechanical Engineers, Part B: Journal of Engineering Manufacture 2006, 220(9):1417-1427.

21. Lindemann C, Jahnke U, Koch R: Analyzing Product Lifecycle Costs for a Better Understanding of Cost Drivers in Additive Manufacturing. In: 2012 Solid Freeform Fabrication Symposium. University of Texas, TX; 2012.

22. Sreenivasan R, Bourell DL: Sustainability Study in Selective Laser Sintering - An Energy Perspective. In: 20th Annual International Solid Freeform Fabrication Symposium. Austin, TX, USA; 2009.

23. Baumers M, Dickens P, Tuck C, Hague R: The cost of additive manufacturing: machine productivity, economies of scale and technology-push. Technological Forecasting and Social Change: An International Journal 2015: in press.

24. Atzeni E, Salmi A: Economics of additive manufacturing for end-usable metal parts. The International Journal of Advanced Manufacturing Technology 2012, 62(9-12):1147-1155.

25. Lipson H, Kurman M: Fabricated: The New World of 3D Printing. Indiapolis, IN: John Wiley \&Sons; 2013.

26. Huang S, Liu P, Mokasdar A, Hou L: Additive manufacturing and its societal impact: a literature review. The International Journal of Advanced Manufacturing Technology 2013, 67(5-8):11911203.

27. Petrovic V, Vicente Haro Gonzalez J, Jordá Ferrando O, Delgado Gordillo J, Ramón Blasco Puchades J, Portolés Griñan L: Additive layered manufacturing: sectors of industrial application shown through case studies. International Journal of Production Research 2010, 49(4):10611079.

28. Fogliatto FS, da Silveira GJC, Borenstein D: The mass customization decade: An updated review of the literature. International Journal of Production Economics 2012, 138(1):14-25.

29. Tuck CJ, Hague RJM, Ruffo M, Ransley M, Adams P: Rapid manufacturing facilitated customization. International Journal of Computer Integrated Manufacturing 2008, 21(3):245-258.

30. Chen D, Heyer S, Ibbotson S, Salonitis K, Steingrímsson JG, Thiede S: Direct digital manufacturing: definition, evolution, and sustainability implications. Journal of Cleaner Production 2015: in press. 
31. Snyder M, Dunn J, Gonzalez E: The Effects of Microgravity on Extrusion Based Additive Manufacturing. In: AIAA SPACE 2013 Conference and Exposition: 2013: American Institute of Aeronautics and Astronautics; 2013.

32. Khajavi SH, Partanen J, Holmström J: Additive manufacturing in the spare parts supply chain. Computers in Industry 2014, 65(1):50-63.

33. Holmström J, Partanen J, Tuomi J, Walter M: Rapid manufacturing in the spare parts supply chain: Alternative approaches to capacity deployment. Journal of Manufacturing Technology Management 2010, 21(6):687-697.

34. Wohlers T: 3D Printing and Additive Manufacturing State of the Industry: Wohlers Associates Inc; 2015.

35. Huang R, Riddle M, Graziano D, Warren J, Das S, Nimbalkar S, Cresko J, Masanet E: Energy and emissions saving potential of additive manufacturing: the case of lightweight aircraft components. Journal of Cleaner Production 2015:in press.

36. Gausemeier J, Echterhoff N, Kokoschka M, Wall M: Thinking ahead the Future of Additive Manufacturing - Analysis of Promising Industries. Pub. Heinz Nixdorf Institute, University of Paderborn, Paderborn: 2011.

37. Mahamood RM, Shukla M, Pityana S: additive manufacturing in surface modification of metals. In: Surface Engineering Techniques and Applications: Research Advancements. Edited by Santo L, Davim JP. Hershey PA: IGI Global; 2014: 223.

38. Gebler M, Schoot Uiterkamp AJM, Visser C: A global sustainability perspective on 3D printing technologies. Energy Policy 2014, 74:158-167.

39. Allen J: An Investigation into the Comparative Costs of Additive Manufacture vs. Machine from Solid for Aero Engine Parts. In: NATO AVT-139 Specialists' Meeting: Cost Effective Manufacture via Net-Shape Processing. Amsterdam, Netherlands: NATO; 2006: Paper 17.

40. Ford SLN: Additive Manufacturing Technology: Potential Implications for U.S. Manufacturing Competitiveness. In: Journal of International Commerce and Economics. Washington DC, US: United States International Trade Commission 2014.

41. Cevolini L: Parts that go on the Final Car. In: International Conference on Future Industrial Applications of Additive Fabrication - Euromold 2006. Frankfurt; 2006.

42. World motor vehicle production [http://www.acea.be/statistics/tag/category/world-production]

43. Naga H, Ravi B, Mukherjee NP: Rapid hard tooling process selection using QFD-AHP methodologynull. Journal of Manufacturing Technology Management 2006, 17(3):332-350.

44. Wang Y, Yu K-M, Wang CCL, Zhang Y: Automatic design of conformal cooling circuits for rapid tooling. Computer-Aided Design 2011, 43(8):1001-1010.

45. Gebhardt A, Schmidt F-M, Hötter J-S, Sokalla W, Sokalla P: Additive Manufacturing by selective laser melting the realizer desktop machine and its application for the dental industry. Physics Procedia 2010, 5, Part B:543-549.

46. Vandenbroucke B, Kruth J-P: Selective laser melting of biocompatible metals for rapid manufacturing of medical parts. Rapid Prototyping Journal 2007, 13(4):196-203.

47. Liu Q, Leu MC, Schmitt SM: Rapid prototyping in dentistry: technology and application. The International Journal of Advanced Manufacturing Technology 2006, 29(3-4):317-335.

48. Cohen A, Chen R: Microfabricated tissue removal instruments for minimally-invasive procedures. In: 19th International Conference of the Society for Medical Innovation and Technology,. Sendai, Japan; 2007.

49. Bose S, Vahabzadeh S, Bandyopadhyay A: Bone tissue engineering using 3D printing. Materials Today 2013, 16(12):496-504. 
50. Jiankang H, Dichen L, Bingheng L, Zhen W, Tao Z: Custom fabrication of a composite hemiknee joint based on rapid prototypingnull. Rapid Prototyping Journal 2006, 12(4):198-205.

51. He Y, Ye M, Wang C: A method in the design and fabrication of exact-fit customized implant based on sectional medical images and rapid prototyping technology. The International Journal of Advanced Manufacturing Technology 2006, 28(5-6):504-508.

52. Lantada AD, Morgado PL: Rapid Prototyping for Biomedical Engineering: Current Capabilities and Challenges. Annual Review of Biomedical Engineering 2012, 14(1):73-96.

53. Melchels FPW, Domingos MAN, Klein TJ, Malda J, Bartolo PJ, Hutmacher DW: Additive manufacturing of tissues and organs. Progress in Polymer Science 2012, 37(8):1079-1104.

54. Kunnari E, Valkama J, Keskinen M, Mansikkamäki P: Environmental evaluation of new technology: printed electronics case study. Journal of Cleaner Production 2009, 17(9):791-799.

55. Vaezi M, Seitz H, Yang S: A review on 3D micro-additive manufacturing technologies. The International Journal of Advanced Manufacturing Technology 2013, 67(5-8):1721-1754.

56. Regenfuss P, Ebert R, Exner H: Laser Micro Sintering - a Versatile Instrument for the Generation of Microparts. Laser Technik Journal 2007, 4(1):26-31.

57. Qin Y: Micro-manufacturing engineering and technology. Pub. Elsevier, Oxford: 2010.

58. Vasquez M, Cross J, Hopkinson N, Haworth B: Developing new laser sintering materials for snowboarding applications. Procedia Engineering 2012, 34:325-330.

59. Chu C, Graf G, Rosen DW: Design for Additive Manufacturing of Cellular Structures. Computer-Aided Design and Applications 2008, 5(5):686-696.

60. Hudson SE: Printing teddy bears: a technique for 3D printing of soft interactive objects. In: Proceedings of the SIGCHI Conference on Human Factors in Computing Systems, ACM Toronto, Canada: 2014: 459-468.

61. McAlea KP, Forderhase PF, Ganninger ME, Kunig FW, Magistro AJ: Selective laser sintering with composite plastic material. US Patent US 5733497 A., 1998

62. Menhennett HE, Brown RB: Apparatus and method for making three-dimensional articles using bursts of droplets. US Patent US 5555176 A, 1996; World patent WO 1996012609 A1, 1996.

63. Deckard CR: Method for producing parts by selective sintering. US Patent US 5597589, 1997.

64. Beaman et al JJ: Solid Freeform Fabrication: A New Direction in Manufacturing: Springer US; 1997.

65. Manyika J: Manufacturing the future: The next era of global growth and innovation: McKinsey Global Institute; 2012: 5.

66. Person L, Rane P: 3D Printing Market (Technologies, Materials, Applications and Geography) Global Opportunity Analysis and Forecast-2013-2020: Allied Market Research, Portland, USA: 2014.

67. Alto P: Global 3D printing market to reach \$20.2 billion in 2019. Canalys, 2015. http://www.canalys.com/newsroom/global-3d-printing-market-reach-202-billion-2019 (accessed $14 / 9 / 15)$

68. Prashant K, Anne M, Debasish D: A review of process planning techniques in layered manufacturingnull. Rapid Prototyping Journal 2000, 6(1):18-35.

69. Pulak Mohan P, Reddy NV, Sanjay GD: Slicing procedures in layered manufacturing: a reviewnull. Rapid Prototyping Journal 2003, 9(5):274-288.

70. Donald AK, Richard PC, Nora RO, George AG, Allan L, Gyoowan H, Akos B, Stan R: Development of a curved layer LOM process for monolithic ceramics and ceramic matrix compositesnull. Rapid Prototyping Journal 1999, 5(2):61-71. 
71. Levy GN, Schindel R, Kruth JP: Rapid manufacturing and rapid tooling with layer manufacturing (LM) technologies, state of the art and future perspectives. CIRP Annals Manufacturing Technology 2003, 52(2):589-609.

72. Gu DD, Meiners W, Wissenbach K, Poprawe R: Laser additive manufacturing of metallic components: materials, processes and mechanisms. International Materials Reviews 2012, 57(3):133-164.

73. Earls A, Baya V: The road ahead for 3-D printers. In: Technology Forecast: The future of 3-D printing. Price Waterhouse Cooper Center for Technology and Innovation; 2014.

74. Pinkerton AJ, Syed W, Li L: Diode Laser Deposition of microstructurally graded components using gas- and water-atomised powder blends. In: 23rd International Congress on Applications of Lasers and Electro-optics (ICALEO): 2004; San Francisco CA USA: Laser Institute of America; 2004: CD.

75. Vreeling JA, Ocelík V, De Hosson JTM: Ti-6Al-4V strengthened by laser melt injection of WCp particles. Acta Materialia 2002, 50(19):4913-4924.

76. Stoneman P: The Economics of Technological Diffusion. Pub. Blackwell, Oxford: 2002.

77. Mellor S, Hao L, Zhang D: Additive manufacturing: A framework for implementation. International Journal of Production Economics 2014, 149:194-201.

78. Kietzmann J, Pitt L, Berthon P: Disruptions, decisions, and destinations: Enter the age of 3-D printing and additive manufacturing. Business Horizons 2015, 58(2):209-215.

79. Hollingsworth B: World's First 3D Printed Metal Gun Successfully Fires 600+ Rounds. In: CNSNews. Washington: Media Research Center; 2013.

80. Doherty D: Downloading Infringement: Patent Law as a Roadblock to the 3D Printing Revolution. Harvard Journal of Law \& Technology 2012, 26(1):353-374.

81. Bullinger (Ed.) H: Technology Guide - Principles, Applications, Trends. Pub. Springer, Berlin, 2009.

82. Clark P: Buying the Big Jets - Fleet planning for airlines, 2 edn. Pub. Ashgate Pub. Co.,Aldershot, UK: 2007.

83. Wohlers T: Additive Manufacturing State of the Industry: Wohlers Associates Inc; 2010.

84. Bourell DL, Leu MC, Rosen DW: Roadmap for Additive Manufacturing: Identifying the Future of Freeform Processing. Pub. The University of Texas, Austin; 2009.

85. Ubair HR: 3D Printed Parts for Quick Turnaround Aircraft Projects and Legacy Issues. In: 15th AIAA Aviation Technology, Integration, and Operations Conference. American Institute of Aeronautics and Astronautics; 2015.

86. Weiss M, Patel MK, Junginger M, Perujo A, Bonnel P, van Grootveld G: On the electrification of road transport - Learning rates and price forecasts for hybrid-electric and battery-electric vehicles. Energy Policy 2012, 48:374-393.

87. Tate E, Harpster M, Savagian P: The Electrification of the Automobile: From Conventional Hybrid, to Plug-in Hybrids, to Extended-Range Electric Vehicles. SAE International Journal of Passenger Cars - Electronic and Electrical and Systems 2009, 1(1):156-166.

88. Gibbs DMR, Vaezi M, Yang S, Oreffo Richard O: Hope versus hype: what can additive manufacturing realistically offer trauma and orthopedic surgery? Regenerative Medicine 2014, 9(4):535-549.

89. Stotko CM: Laser sintering: Layer by layer. Nature Photonics 2009, 3(5):265-266.

90. Mosadegh B, Xiong G, Dunham S, Min JK: Current progress in 3D printing for cardiovascular tissue engineering. Biomedical Materials 2015, 10(3):034002. 
91. Hoerber J, Glasschroeder J, Pfeffer M, Schilp J, Zaeh M, Franke J: Approaches for Additive Manufacturing of 3D Electronic Applications. Procedia CIRP 2014, 17:806-811.

92. Gress DR, Kalafsky RV: Geographies of production in 3D: Theoretical and research implications stemming from additive manufacturing. Geoforum 2015, 60(0):43-52.

93. Saberi S, Mohd. Yusuff RM, Zulkifli N, Ahmad MMHM: Effective Factors on Advanced Manufacturing Technology Implementation Performance: A Review. Journal of Applied Sciences 2010, 10:1229-1242.

94. Hopkinson N, Hague R, Dickens P: Rapid Manufacturing: An Industrial Revolution for the Digital Age. Pub. Wiley-Blackwell, Chichester, UK: 2005.

95. Gilbert CG: Unbundling the Structure of Inertia: Resource Versus Routine Rigidity. Academy of Management Journal 2005, 48(5):741-763.

96. Schlumberger CE: Air Transport and Energy Efficiency TP - 38. The International Bank for Reconstruction and Development / The World Bank, Washington DC: 2012.

97. Oxford Economics, Benefits Beyond Borders, 2014: 7; http://aviationbenefits.org/media/26786/ATAG_AviationBenefits2014_FULL_LowRes.pdf (accessed 14/9/15)

98. Direct metal laser sintering could be 'better than' rapid investment casting for aerospace parts. Metal Powder Report 2014, 69(2):41.

99. Telenko C, Seepersad CC: A comparison of the energy efficiency of selective laser sintering and injection molding of nylon parts. Rapid Prototyping Journal 2012, 18(6):472-481.

100. Drizo A, Pegna J: Environmental impacts of rapid prototyping: an overview of research to date. Rapid Prototyping Journal 2006, 12(2):64-71.

101. Burkhart M, Aurich JC: Framework to Predict the Environmental Impact of Additive Manufacturing in the Life Cycle of a Commercial Vehicle. Procedia CIRP 2015, 29(0):408-413.

102. Luo Y, Leu MC, Ji Z: Assessment of environmental performance of rapid prototyping and rapid tooling process. In: Solid Freeform Fabrication Symposition. Edited by Bourell DL, Beaman J, Crawford RH. Austin, TX; 1999: 783-791.

103. Le Bourhis F, Kerbrat O, Dembinski L, Hascoet J-Y, Mognol P: Predictive Model for Environmental Assessment in Additive Manufacturing Process. Procedia CIRP 2014, 15:26-31.

104. Von der Gracht HA, Darkow I-L: Scenarios for the logistics services industry: A Delphi-based analysis for 2025. International Journal of Production Economics 2010, 127(1):46-59.

105. Cohen A, Kruglick E: EFAB technology and applications. In: The MEMS handbook. Edited by Gad-el-Hak M, vol. 2. CRC Press, Boca Raton: 2006.

106. Karunakaran KP, Suryakumar S, Pushpa V, Akula S: Low cost integration of additive and subtractive processes for hybrid layered manufacturing. Robotics and Computer-Integrated Manufacturing 2010, 26(5):490-499.

107. Duflou JR, Sutherland JW, Dornfeld D, Herrmann C, Jeswiet J, Kara S, Hauschild M, Kellens K: Towards energy and resource efficient manufacturing: A processes and systems approach. CIRP Annals - Manufacturing Technology 2012, 61(2):587-609.

108. Kerbrat O, Mognol P, Hascoët J-Y: A new DFM approach to combine machining and additive manufacturing. Computers in Industry 2011, 62(7):684-692.

109. Tabucanon MT, Batanov DN, Verma DK: Decision support system for multicriteria machine selection for flexible manufacturing systems. Computers in Industry 1994, 25(2):131-143.

110. Smith PC, Lupeanu M-E, Rennie AEW: Additive manufacturing technology and material selection for direct manufacture of products based on computer aided design geometric feature analysis. International Journal of Materials and Structural Integrity 2012, 6(2-4):96-110. 
Table 1. Categories of Additive manufacturing, classified according to ASTM Standard F2792 [9]

\begin{tabular}{|c|c|c|c|}
\hline Category & Description & Processes & Laser \\
\hline Binder jetting & $\begin{array}{l}\text { A liquid bonding agent is selectively deposited to join } \\
\text { powder materials. }\end{array}$ & Three dimensional printing (3DP) & No \\
\hline $\begin{array}{l}\text { Directed energy } \\
\text { deposition }\end{array}$ & $\begin{array}{l}\text { Focused thermal energy is used to fuse } \\
\text { materials by melting as they are being deposited. }\end{array}$ & $\begin{array}{l}\text { Direct metal deposition (DMD), Direct laser deposition, } \\
\text { laser engineered net shaping (LENS), Multiple layer laser } \\
\text { cladding }\end{array}$ & Yes $^{A}$ \\
\hline Material extrusion & $\begin{array}{l}\text { Material is selectively dispensed through a nozzle or } \\
\text { orifice. }\end{array}$ & $\begin{array}{l}\text { Fused Deposition Modelling (FDM), Fused Filament } \\
\text { Fabrication (FFF), Pressure-based Extrusion (PBE) }\end{array}$ & No \\
\hline Material jetting & Droplets of build material are selectively deposited & $\begin{array}{l}\text { Polyjet, Aerosol Jet (AJ) ( sometimes also termed three } \\
\text { dimensional printing ) }\end{array}$ & No \\
\hline Powder bed fusion & $\begin{array}{l}\text { Thermal energy selectively fuses regions of a powder } \\
\text { bed. }\end{array}$ & $\begin{array}{l}\text { Selective laser melting (SLM) and Selective laser sintering } \\
\text { (SLS). }\end{array}$ & Yes ${ }^{B}$ \\
\hline Sheet lamination & Sheets of material are bonded to form an object & $\begin{array}{l}\text { Ultrasonic additive manufacturing (UAM) and Laminated } \\
\text { object manufacturing (LOM) }\end{array}$ & No \\
\hline $\begin{array}{l}\text { Vat } \\
\text { photopolymerisation }\end{array}$ & $\begin{array}{l}\text { Liquid photopolymer in a vat is selectively } \\
\text { cured by light-activated polymerization }\end{array}$ & Stereolithography (SLA) & Yes \\
\hline
\end{tabular}

\footnotetext{
${ }^{\text {A }}$ An electron beam can also be used for wire feed directed energy deposition;

${ }^{\text {B }}$ An electron beam can also be used
} 